\title{
JEMAAT AHMADIYAH DAN RESPON MASYARAKAT DI KABUPATEN BUTON
}

\section{Congregation of Ahmadiyah and Public Response in Buton Regency}

\author{
Sabara \\ Balai Penelitian dan Pengembangan Agama Makassar \\ Jl. A.P. Pettarani No. 72 Makassar \\ Email: barack_filsafat@yahoo.co.id
}

Naskah diterima tanggal 7 Maret 2014. Naskah direvisi tanggal 8 Agustus 2014. Naskah disetujui tanggal 11 Agustus 2014

\begin{abstract}
Abstrak
Penelitian ini bertujuan untuk menelusuri eksistensi jemaat Ahmadiyah di kabupaten Buton serta respon masyarakat terhadap keberadaan jemaat Ahmadiyah. Penelitian ini berfokus pada dua masalah penelitin, yaitu: bagaimana eksistensi dan perkembangan jamaat Ahmadiyah di kabupaten Buton serta bagaimana respon masyarakat terhadap keberadaan jemaat Ahmadiyah di kabupaten Buton. Penelitian menggunakan metode kualitatif dengan teknik pengumpulan data melalui wawancara dan observasi, analisis data dengan metode deskriptif-analitis. Ahmadiyah di kabupaten Buton telah ada sejak tahun 1983 dibawa oleh dua orang warga Buton yang telah menganut Ahmadiyah aliran Qadian di Jakarta. Hingga saat ini terdata 53 orang jemaat Ahmadiyah di Buton dan tinggal di kelurahan Saragi, kecamatan Pasarwajo. Hubungan antara jemaat Ahmadiyah dan masyarakat sekitar tidak harmonis, masyarakat merespon keberadaan jemaat Ahmadiyah dengan sikap resistensi yang tinggi, bahkan bermuara pada konflik horisontal pada tahun 2006, 2007, 2009, dan 2010. Saat ini, jemaat Ahmadiyah di Buton tidak dapat lagi melakukan aktivitas keagamaan.
\end{abstract}

Kata kunci: jemaat Ahmadiyah, Kabupaten Buton, respon masyarakat.

\begin{abstract}
This research is aimed to explore the existence of Ahmadiyah congregation in Buton regency and the public response to the existence of Ahmadiyah congregation. This research focuses on two research problems are how the existence and development of the Ahmadiyah congregation in Buton regency and how the public response to the existence of Ahmadiyah congregation in Buton regency. This research uses qualitative methods of data collection techniques by using interviews and observations, data analysis with descriptive-analytical method. Ahmadiyah in Buton regency has existed since 1983 which was brought by two buton citizen who have embraced Ahmadiyah of Qadian religious sect in Jakarta. Right now the Ahmadiyah congregation have been recorded 53 people living in the Saragi village, District of Pasarwajo. The relationship between Ahmadiyah congregation and the surroundings community are not harmonious. Public responsed to the existence of Ahmadiyah congregation with a high resistance attitude, even created the horizontal conflicts in 2006, 2007, 2009, and 2010. Currently, Ahmadiyah in Buton can't carry out its religious activities anymore.
\end{abstract}

Keywords: congregation of Ahmadiyah, Buton regency, public response

\section{PENDAHULUAN}

alah satu aliran keagamaan dalam Islam yang hadir akibat perbedaan dalam interpretasi beberapa hal pokok dalam ajaran Islam adalah Ahmadiyah yang lahir di wilayah Anak benua India pada tahun 1889 bertepatan dengan tahun 1306 H (Nahdi, 2001: 5). Setelah satu abad lebih, akhirnya Ahmadiyah berkembang luas ke seluruh belahan dunia, termasuk ke Indonesia. 
Ahmadiyah masuk ke Indonesia sejak tahun 1924 (Kurniawan, 2006: 24). Meski telah hampir seabad keberadaan Ahmadiyah di Indonesia, keberadaan jemaat Ahmadiyah, khususnya aliran Qadian, kerap memicu penolakan bahkan konflik dengan umat Islam yang lain, yang menganggap Ahmadiyah telah menyimpang dari ajaran Islam yang sesungguhnya. Kasus penyerangan markas Ahmadiyah di Parung, Bogor pada tahun 2006, pengusiran warga Ahmadiyah di Mataram, dan penyerangan warga Ahmadiyah di Cikesik, Banten dan di beberapa daerah lain di Indonesia, bahkan beberapa kepala daerah mengeluarkan peraturan terkait pelarangan Ahmadiyah di daerahnya. Hal tersebut merupakan fakta akan adanya penolakan besar atas keberadaan dan perkembangan jemaat Ahmadiyah.

Menyikapi kondisi Ahmadiyah yang dianggap telah meresahkan karena dianggap merubah salah satu doktrin dasar dalam Islam, yaitu tentang akhir kenabian. Pemerintah kemudian mengeluarkan SKB 3 menteri, yaitu Menteri Agama, Jaksa Agung dan Menteri Dalam Negeri Nomor 3 Tahun 2008, Nomor Kep 33/A/JA/6/2008, Nomor 199 Tahun 2008 tentang Peringatan dan Perintah kepada Penganut, Anggota dan/atau Anggota Pengurus Jemaat Ahmadiyah Indonesia (JAI) dan warga masyarakat.

Ahmadiyah adalah salah satu aliran Islam yang didirikan oleh Mirza Ghulam Ahmad (18391908) di Qadian, Punjab India. Jemaat Ahmadiyah di dirikan ketika Ghulam Ahmad menerima bai'at (sumpah setia) 40 orang pengikutnya di Ludhiana, Punjab pada tanggal 23 Maret 1889. Setahun sebelumnya, Ghulam Ahmad menyatakan dirinya telah menerima petunjuk Tuhan untuk menerima bai'at (Massoweang, dalam Ahmad (ed), 2007: 21). Kelahiran Ahmadiyah dilatarbelakangi oleh beberapa faktor, baik internal maupun eksternal. Kondisi sosial umat Islam yang statis dan mengalami banyak kemunduran di berbagai bidang kehidupan merupakan faktor internal lahirnya gerakan Ahmadiyah. Selain itu secara eksternal umat Islam mengalami serangan kaum misionaris di berbagai belahan dunia Islam (Zulkarnaen, 2005: 311) merupakan faktor eksternal yang memicu kelahiran Ahmadiyah.

Menurut Saleh Nahdi (2001: 14-15), kelahiran Ahmadiyah berorientasi pada pembaharuan pemikiran. Tujuan Ahmadiyah didirikan adalah untuk memperbaiki kehidupan beragama orang Islam dan mempersatukan umat Islam. Orientasi pada pembaharuan pemikiran tersebut, membuat
Ahmadiyah menurut Gibb (1995: 104) adalah satusatunya sekte dalam Islam yang berhasil melakukan gerakan pembaharuan dengan cara yang khas liberal dan cinta damai dengan maksud menarik kepercayaan masyarakat umum terhadap Islam.

Ahmadiyah meyakini bahwa Mirza Ghulam Ahmad adalah Imam Mahdi, al-Masih Mau'ud dan Nabi. Namun, kenabian yang diyakini tidaklah membawa syariat baru dan hanya mengakui syariat yang telaha da, yaitu syariat Nabi Muhammad saw. Dalam hal ini, Ghulam Ahmad hanya berperan sebagai pelanjut dari apa yang telah dibawa oleh Nabi Muhammad saw. Namun, bagi sebagian umat Islam, pandangan ini dinilai sebagai permulaan dari perdebatan dan berakhir dengan permusuhan antara Ahmadiyah dan mayoritas umat Islam. Karena menurut mayoritas umat islam Ahmadiyah telah masuk ke dalam wilayah prinsipil yang tidak bisa ditawar lagi (Kurniawan, 2006), yaitu soal akhir kenabian. Keyakinan tersebut bahkan direspon oleh filosof muslim asal Anak Benua India dalam Bukunya "Islam dan Ahmadiyah", Iqbal (1991: 13) menyatakan keyakinan Hmadiyah tentang kenabian Ghulam Ahmad adalah "penyimpangan dan bid'ah besar"

Selain keyakinan tentang kenabian Ghulam Ahmad, yang berarti bahwa Ahmadiyah meyakini bahwa pintu kenabian masih terbuka setelah Nabi Muhamamd, ada beberapa keyakinan lain yang dianut oleh Ahmadiyah yang berbeda dengan yang dianut oleh mainstream umat Islam. Keyakinan tersebut adalah mengenai wafatnya Nabi Isa alMasih as, di mana mayoritas umat Islam meyakini bahwa Nabi isa as belum wafat. Keyakinan lainnya adalah kedatangan al-Masih dan al-Mahdi, yaitu Mirza Ghulam Ahmad sendiri. Keyakinan tentang jihad dengan mengangkat senjata sebagai jihad yang paling rendah yang mengesankan bahwa ajaran Ahmadiyah menyepelekan jihad dan melemahkan semangat jihad umat Islam, memicu kontroversi dengan mayoritas umat Islam di anak Benua India yang waktu itu sedang berjuang melawan penjajahan Inggris. Keyakinan lainnya adalah wajib adanya khilafah.

Pasca wafatnya Ghulam Ahmad di tahun 1908, kepemimpinan Jemaat Ahmadiyah dilanjutkan oleh Hakim Nuruddin sebagai khalifah I yang memipin Jemaat Ahmadiyah hingga tahun 1914. Pasca Hakim Nuruddin, Jemaat Ahmadiyah mengalami perpecahan menjadi dua kelompok yaitu kelompok Qadian dan kelompok Lahore. Perpecahan ini dipicu oleh perbedaan pandangan mengenai Khalifah, 
Iman kepada Ghulam Ahmad, dan masalah kenabian (Ahmad, 1997: 71). Kelompok Lahore adalah kelompok Ahmadiyah yang mengangggap khalifah II adalah khalifah Muhammad Ali berbeda dengan kelomppok Qadian yang mengangkat Mirza Basyiruddin Ahmad sebagai khalifah ke II. Perbedaan lainnya antara kedua kelompok tersebut adalah mengenai kepercayaan apakah Ghulam Ahmad adalah nabi atau tidak. Menurut kelompok Lahore, Ghulam Ahmad hanyalah seorang mujaddid dan bukan nabi. Kelompok Lahore berpandangan bahwa, kelompok Qadian sejak khalifah mereka yang kedua telah mendeklarasikan agama baru dengan menjadikan Mirza Ghulam Ahmad sebagai nabi (Yasir, 1981: 50).

Setelah khalifah kedua (Basyiruddin Ahmad) wafat pada tahun 1965, digantikan oleh Mirza Natsir Ahmad sebagai Khalifatul Masih III hingga tahun 1982. Khalifah IV dijabat oleh Mirza Thahir Ahmad sejak tahun 1982 hingga tahun 2003. Dan yang menjabat sebagai Khalifah ke $\mathrm{V}$ bagi jemaat Ahmadiyah saat ini adalah Mirza Masroor Ahmad. Kini jemaat Ahmadiyah telah tersebar di 184 negara dan memiliki anggota lebih dari 200 juta orang (Massoweang, 2007: 24).

Dalam perkembangannya, baik aliran Qadian maupun Lahore melakukan pelebaran sayap organisasi dan dakwah kelompoknya ke berbagai negara di dunia, termasuk Indonesia. Ahmadiyah masuk ke Indonesia pada tahun 1924 Perluasan jaringan dakwah Ahmadiyah aliran Qadian berlangsung pada masa kepemimpinan khalifah ke II, Basyiruddin Ahmad. Tetapi, sebelum Ahmadiyah Qadian masuk di Indonesia, aliran Lahore adalah yang pertama masuk melalui para muballighnya yang datang sebagai pedagang. Ada karakteristik yag berbeda di antara kedua aliran tersebut dalam penyebaran gerakannya. Aliran Lahore banyak menggunakan cara penyebarannya melalui pengiriman muballigh-muballigh ke berbagai negara meskipun tanpa undangan dari negara tersebut. Sementara aliran Qadian menyebarkan sayapnya ke Indonesia melalui para santri yang mondok di pesantren Sumatera Thawalib dan melanjutkan sekolah keQadian, kemudian kembali ke Indonesia dan menyebarkan ajaran Ahmadiyah. Sedangkan menurut Hamka, proses pengenalan ajaran Ahmadiyah di Indonesia pada awalnya banyak melalui informasi yang didapatkan mellalui majalah-majalah yang terbit di luar negeri dan masuk ke Indonesia (Kurniawan: 24).
Gerakan Ahmadiyah di Indonesia sempat menua perselisihan dengan ormas Islam besar, khususnya Muhammadiyah.Puncak perselisihan dengan Muhammadiyah terjadi pada muktamar Muhammadiyah 1926. Salah satu agenda muktamar adalah membahas soal Ahmadiyah, dan akhirnya kongres tersebut memutuskan memberikan opsi kepada anggota Muhammadiyah yang menjadi anggota Ahmadiyah. Akhirnya, beberapa orang tokoh Muhammadiyah yang juga anggota Ahmadiyah waktu itu keluar. Ketika HOS Tjokroaminoto (tokoh SI) menerjemahkan the Holy Quran karya Maulana Muhammad Ali, khalifah Ahamdiyah Lahore pertama, mendapatkan penentangan yang cukup kuat. Penentangan ini berakibat terjadinya perpecahan di tubuh SI pada waktu itu (Noer, 1982: 154).

Dimulai dari Padang, Ahmadiyah aliran Qadian menyebar ke pulau Jawa, setelah Rahmat Ali, seorang tokoh Ahmadiyah meninggalkan Padang menuju Jawa, hasilnya pada tahun 1932 berdiri cabang Ahmadiyah di Batavia (Jakarta), setahun sesudahnya berdiri cabang di Bogor. Setalah sepuluh tahun, Ahmadiyah di Indonesia telah memiliki 3 cabang, yaitu Padang, Jakarta, dan Bogor, untuk itu dibentuk pengurus besar Jemaat Ahmadiyah Indonesia, yang saat itu bernama Anjuman Ahmadiyah Qadian Departemen Indonesia (AQDI), pada tahun 1937, dan nama tersebut berubah menjadi Jemaat Ahmadiyah Indonesia (JAI) pada saat kongres 1948. Sebagai sebuah organisasi mendapatkan legalitas dari pemerintah sebagai badan hukum melalui SK Menteri Kehakiman, No J.A/5/23/13 tanggal 13 Maret 1953 dan diumumkan dalam Berita Negara Republik Indonesia Nomor 26 tanggal 31 Maret 1953 (Masaweang:26). Saat ini 181 jemaat lokal (cabang) Ahmadiyah telah berdiri di seluruh provinsi di Indonesia, yang berpusat di Bogor sejak tahun 1987 (Nahrawi, dalam Ahmad (ed), 2007: 187).

Sedangkan untuk Ahmadiyah aliran Lahore, sejak tahun 1928 telah membentuk wadah berkumpul dengan nama Gerakan Ahmadiyah Indonesia Centrum Lahore. Pada tahun 1929 mendapatkan legalitas badan hukum dengan nama Gerakan Ahmadiyah Indonesia (GAI) (Kurniawan: 33). Hingga saat ini, GAI juga telah memiiki puluhan cabang di Indonesia, dan berpusat di Yogyakarta.

Sebagaimana telah disebutkan sebelumnya, bahwa sejak awal keberadaan Ahmadiyah di Indonesia, khususnya aliran Qadian telah mendapatkan penentangan dan reaksi keras 
dari umat Islam yang lain. Ahmadiyah Qadian mendapatkan stigma sebagai kelompok yang telah menyimpang bahkan telah keluar dari Islam karena meyakini kenabian Mirza Ghulam Ahmad. Puncak dari penentangand an reaksi keras tersebut adalah penyerangan atas kampus Mubarok yang merupakan markas pusat Jemaat Ahamdiyah Indonesia di Parung, Bogor pada tanggal 15 Agustus 2005. Selanjutnya berbagai kasus penyerangan terhadap warga Ahmadiyah terjadi di Mataram pada tahun 2006, bahkan hingga kini jemaat Ahmadiyah di Mataram amsih tinggal di pengungsian. Dan yang cukup menghebohkan adalah penyerangan terhadap kelompok Ahamdiyah di Cikesik, Pandeglang Banten pada tahun 2012.

Menyikapi reaksi masyarakat terhadap Ahmadiyah, Pemerintah kemudian mengeluarkan SKB 3 menteri, yaitu Menteri Agama, Jaksa Agung dan Menteri Dalam Negeri Nomor 3 Tahun 2008, Nomor Kep 33/A/JA/6/2008, Nomor 199 Tahun 2008 tentang Peringatan dan Perintah kepada Penganut, Anggota dan/atau Anggota Pengurus Jemaat Ahmadiyah Indonesia (JAI) dan warga masyarakat. SKB tersebut berisi enam butir yang diantaranya memerintahkan kepada penganut, anggota dan atau anggota pengurus Jemaat Ahmadiyah indonesia (JAI), sepanjang mengaku beragama Islam, untuk menghentikan penyebaran penafsiran dan kegiatan yang menyimpang dari pokok-pokok ajaran agama Islam. Yaitu penyebaran paham yang mengakui adanya nabi dengan segala ajarannya setelah Nabi Muhammad SAW. Bagi pelanggarnya dapat dikenai sanksi hukum termasuk badan hukum dan organisasinya, Sejak tahun 1980, Majelis Ulama Indonesia (MUI) dalam Musyawarah Nasional (Munas) kedua mengeluarkan fatwa yang antara lain isinya menyatakan bahwa Ahmadiyah adalah jemaat di luar Islam yang sesat dan menyesatkan. Kemudian pada munas ketujuh tahun 2005, MUI menegaskan kembali fatwa tahun 1980 bahwa Ahmadiyah berada di luar Islam, sesat dan menyesatkan, serta orang islam yang mengikutinya adalah murtad, dan pemerintah berkewajiban untuk melarang penyebaran paham Ahamdiyah di Indonesia dan membekukan organisasinya.

Konflik horisontal antara masyarakat penganut Islam mainstream dengan warga yang menganut aliran Ahmadiyah, juga terjadi di. Kabupaten Buton, provinsi Sulawesi Tenggara. Di daerah ini pernah merekam gesekan sosial antara kedua kelompok tersebut, yaitu dalam kisaran tahun 2006 hingga 2010. Keberadaan jamaah
Ahmadiyah yang telah masuk di Buton sejak tahun 1983, tepatnya di kelurahan Saragi, kecamatan Pasarwajo awalnya tidak melahirkan konflik fisik. Namun, karena terpengaruh eskalasi nasional dalam hal penyikapan terhadap Ahmadiyah, maka konflik horisontal itu pun tak bisa dihindari. Hingga kini berdasarkan data Kantor Kementerian Agama Kabupaten buton, terdapat 53 orang pengikut Ahmadiyah yang masih tinggal di kelurahan Saragi.

Penelitian ini berfokus untuk menjawab dua masalah penelitian, yaitu: Bagaimana eksistensi dan perkembangan jemaat Ahmadiyah di Kabupaten Buton? dan Bagaimana Respon masyarakat terhadap keberadaan jemaat Ahmadiyah di kabupaten Buton? Penelitian ini menjadi penting untuk mengetahui bagaimana perkembangan jemaat Ahmadiyah di Buton serta bagaimana respon masyarakat menyikapi keberadaan jemaat Ahmadiyah.

Penelitian ini bertujuan untuk menelusuri eksistensi dan perkembangan serta model dakwah jemaat Ahmadiyah di Kabupaten Buton. selain itu, penelitian ini juga ditujukan untuk melacak respon masyarakat terhadap keberadaan jemaat Ahmadiyah baik interaksi sosial maupun konflik sosial yang terjadi diantara kedua kelompok tersebut.

\section{METODE PENELITIAN}

Penelitian ini merupakan penelitian kualitatif dengan memberikan analisis deskriptif. Pengumpulan data dilakukan lewat wawancara mendalam, observasi, dan dokumentasi. Pemilihan informan secara purposive sampling, yakni menentukan secara sengaja orang-orang yang akan ditetapkan sebagai informan. Informan terdiri atas pihak kementerian agama kabupaten Buton, tokoh Ahmadiyah di Buton, tokoh agama di Buton,d an masyarakat yag tinggal di sekitar komunitas Ahmadiyah.

Pengolahan dan analisis data dilakukan dengan deskriptif-analitis. Yaitu dengan menelaah seluruh data yang tersedia dari berbagai sumber, yaitu hasil wawancara, catatan lapangan, dokumendokumen, dan lain-lain. Kemudian mereduksi data, selanjutnya menyusun ke dalam satuan-satuan, lalu dikategorisasi. Proses selanjutnya adalah mengkonstruksi hubungan antar kategori, lalu disusun dalam bentuk tulisan deskriptif.

\section{PEMBAHASAN}

Secara geografis kabupaten Buton terletak pada garis koordinat 4'90' - 6'25' lintang selatan dan $120^{\prime}-123^{\prime}$ bujur timur. Setelah pemekaran, 
kabupaten Buton memiliki luas wilayah daratan seluas 2.488,71 Km2. Wilayah kabupaten Buton adalah sebagian wilayah pulau Buton, sebagian wilayah pulau Muna, serta sebagian pulau-pulau di sekitar kepulauan Buton. Kabupaten Buton di sebelah Utara berbatasan dengan kabupaten Muna, Sebelah selatan berbatasan dengan Laut Flores, sebelah Barat berbatasan dengan kabupaten Bombanna, serta sebelah Timur berbatasan dengan kabupaten Wakatobi (BPS Kabupaten Buton, 2012: 3).

Berdasarkan data dari kantor BPS kabupaten Buton, penduduk kabpuaten Buton pada tahun 2011 berjumlah 260.801 jiwa atau 54.230 kepala keluarga yang tersebar di 21 kecamatan yang ada. Dengan rasio gender adalah 126.891 jiwa atau 48,65\% penduduk laki-laki dan 131.910 atau 51,35\% adalah penduduk perempuan, dengan demikian rasio gender adalah 94,76. Laju pertumbuhan penduduk setiap tahunnya adalah rata-rata $0,57 \%$. Dengan kepadatan penduduk rata-rata $105 \mathrm{jiwa} / \mathrm{km} 2$.

Berdasarkan data dari Kementerian Agama kabupaten Buton tahun 2011, terdapat 4 agama yang ada di Buton. Populasi umat Islam merupakan umat mayoritas dengan jumlah 270.288 jiwa atau $99 \%$ dari jumlah penduduk Buton. Sedangkan penganut agama Kristen berjumlah 1046 jiwa atau 0,4\% dari jumlah penduduk, penganut Katolik berjumlah 457 jiwa atau $0,17 \%$ dari jumlah penduduk, dan penganut agama Hindu sebanyak 1.278 jiwa atau $0,43 \%$.

Populasi umat non-muslim adalah pendatang dari Toraja, Jawa, Ambon, dan Batak, serta sebagian kecil penduduk asli Buton untuk umat Kristen dan Katolik. Untuk penganut agama Hindu adalah penduduk transmigran asal Bali. Salah satu faktor terpenting yang menjadi ciri dan corak masyarakat Buton hingga hari ini adalah nilai-nilai Islam. Islam sebagai realitas yang tak terelakkan dalam sejarah dan kehidupan masyarakat Buton. Transformasi nilai-nilai Islam dalam tubuh budaya masyarakat Buton terkait erat dengan penetapan Islam sebagai agama resmi kerajaan sejak abad ke XVI (Alifuddin, 2007: 312).

\section{Eksistensi dan Gerak Dakwah Jemaat Ahmadiyah di Buton}

Menurut data dari kementerian Agama Kabupaten Buton, Jemaat Ahamdiyah ditengarai telah berada di kabupaten Buton sejak tahun 1986 dibawa dari Jakarta dan Kendari. Namun, menurut informasi yang peneliti dapatkan dikelurahan Saragi, tempat jemaat Ahmadiyah bermukim, keberadaan Jemaat Ahamdiyah di daerah tersebut sejak tahun 1983. Kehadiran jemaat Ahmadiyah di daerah tersebut, diawali dari dua orang warga Saragi, yaitu Syamsuri La Una dan La Rangani, mendapatkan ajaran Ahmadiyah, sewaktu mereka merantau ke Jakarta sekitar awal dekade 1980-an. Syamsuri La Una datang kembali ke kampung halamannya di Saragi pada tahun 1983 dan berusaha menyebarkan paham yang dianutnya, setelah sebelumnya singgah di Kendari. 1986 La Rangani yang juga menganut paham Ahmadiyah Qadian datang ke Saragi untuk membantu Syamsuri dalam mengembangkan ajaran Ahmadiyah di daerah tersebut.

Melalui pendekatan kekeluargaan dan dakwah yang bersifat personal, sedikit demi sedikit keduanya mendapatkan pengikut dan akhirnya membentuk komunitas Ahmadiyah yang berlokasi di kelurahan Saragi. Seiring dengan berkembangnya jumlah pengikut, maka sering didatangkan muballigh Ahmadiyah dari Jakarta dan Kendari guna mengajarkan paham Ahmadiyah Qadian kepada warga sekitar. Pertemuan demi pertemuan serta pengajian rutin sering dilakukan di rumah jemaat Ahmadiyah.

Dakwah yang dilakukan kepada warga sekitar dilakukan dengan mengajak dialog dan membagikan buku-buku yang berisi ajaran Ahmadiyah. Menurut penuturan ibu Salama (guru MTs Saragi), sewaktu dia masih kecil di sekitar tahun 1980-an, orangorang Ahmadiyah kerap datang ke rumahnya untuk mendakwahi ayahnya dan mengajak masuk Ahmadiyah, namun oleh ayahnya ditolak. Dakwah yang intensif dengan pemahaman keislaman yang berbeda dengan mainstream anutan keislaman masyarakat, membuat keberaadaan jemaat Ahmadiyah di daerah tersebut sering mendapatkan penentangan. Ditambah lagi warga menaytakan resah dengan aktivitas warga Ahmadiyah yang sering mendatangkan muballigh bahkan jemaat Ahmadiyah dari daerah lain untuk tinggal di Saragi.

Kelurahan Saragi merupakan satu-satunya daerah yang menajdi basis jemaat Ahmadiyah di wilayah Buton Raya. Kelurahan Saragi Keluarahan Saragi merupakan salah satu kelurahan di kecamatan Pasarwajo dengan letak $2 \mathrm{~km}$ dari pusat ibukota kabupaten Buton. Kelurahan Saragi memiliki luas $1,38 \mathrm{Km} 2$ dengan jumlah penduduk 2.115 jiwa, yang terdiri atas 1.092 laki-laki dan 1.023 perempuan serta 499 kepala keluarga. Seluruh masyarakat Saragi adalah penganut muslim dan sebagian diantaranya adalah anggota organisasi NU, 53 
orang teridentifikasi sebagai anggota Ahmadiyah. Sebagian besar masyarakat Saragi adalah petani dan sebagian kecil adalah pedagang, pekerja swasta, dan PNS.

Keberadaan yang telah hampir tiga dekade tak cukup membuat jemaat Ahmadiyah berkembang di Buton. Hal ini terbukti hingga tahun 2011 hanya 53 orang yang ditengarai sebagai anggota jemaat Ahamdiyah. Jemaat Ahmadiyah di kabupaten Buton hanya bermukimdi kelurahan Saragi, kecamatan Pasarwajo. Warga Buton, khususnya di Saragi menunjukkan resistensi yang cukup tinggi terhadap keberadaan jemaat Ahmadiyah yang ada disekitar mereka/ Resistensi warga terhadap keberadaan jemaat Ahmadiyah memuncak hingga sempat mengalami bentrokan beberapa kali dengan warga sekitar dan puncaknya pada tahun 2010 dan pasca bentrokan ini aktivitas jemaat Ahmadiyah di daerah tersebut dapat dikatakan berhenti, meski beberapa jamaahnya masih bermukim di daerah tersebut.

Dakwah Ahmadiyah dapat dikatakan tidak berkembang ke desa lain di Buton. Selama hampir 3 dekade geliat dakwah Ahmadiyah Qadian di daerah ini tidak berkembang ke wilayah lainnya di Buton. Data Kementerian Agama mensinyalir ada sekitar 53 jemaat Ahmadiyah yang ada di sini, namun berdasarkan temuan peneliti jemaat Ahmadiyah yang tersisa tinggal 6 kepala keluarga saja. Jumlah tersebut menurun drastis sejak pecah konflik horisontal sejak tahun 2006.

Banyak jemaat Ahmadiyah yang keluar dari Saragi dan bahkan menyatakan keluar dari Ahmadiyah karena faktor tekanan sosial. Sejak awal interaksi antara jemaat Ahmadiyah dan masyarakat setempat tidaklah harmonis, dan ketidakharmonisan ini kemudian bermuara pada konflik yang pecah sejak tahun 2006 dan disusul tahun 2007, 2009, dan 2010. Jemaat Ahmadiyah di Saragi, saat ini dipimpin oleh bapak Lampio, dan aktivitas keagamaan mereka telah benar-benar terbatasi, khsuusnya pasca konflik dengan warga sekitar. Jemaat Ahmadiyah yang masih tinggal di Saragi merupakan penduduk asli dan masih memiliki hubungan kekerabatan dengan warga sekitar. Aktivitas keagamaan hanya sebatas shalat berjamaah yang dilakukan di rumah bapak Lampio. Sejak tahun 2010, pengajian dan pertemuan rutin jemaat Ahmadiyah sudah tidak dilakukan lagi. Warga masyarakat melakukan isolasi terhadap jemaat Ahmadiyah dengan melarang setiap pertemuan serta melarang kedatangan muballigh atau tamu dari jemaat Ahmadiyah dari daerah lain untuk datang ke Saragi.

\section{Respon Masyarakat terhadap Jemaat Ahmadiyah}

Ahmadiyah bukan sesuatu yang asing bagi masyarakat kelurahan Saragi. Hal ini mengingat keberadaan jemaat Ahmadiyah telah hampir tiga dekade berada di kelurahan mereka. Pengetahuan mereka tentang Ahmadiyah sebagai aliran yang dianggap sesat atau sempalan, menunjukkan bahwa informasi tentang aliran Ahmadiyah sebagai aliran sesat atau sempalan dalam Islam telah tersosialisasi kepada masyarakat kelurahan Saragi, sehingga wajar saja jika Ahmadiyah telah terrekan dalam ruang mindset berpikir masyarakat Saragi sebagai aliran yang dianggap sesat atau sempalan.

Yang dipersoalkan oleh warga Saragi, menurut penuturan Ibu Waode Anari (kepala MTs Saragi) tidak sekedar perbedaan teologis atau tata cara fikih saja. Melainkan, sikap sosial warga Ahmadiyah yang cenderung meresahkan warga, seperti sering menyalahkan keyakinan keislaman warga yang lainnya, tidak mau diimami oleh orang yang bukan dari komunitas mereka dalam shalat, serta seringnya datang orang-orang dan tokoh/ muballigh Ahmadiyah dari luar ke Saragi dan membuat kegiatan, hingga upaya Ahmadiyahisasi di Saragi. Inilah yang membuat respon negatif begitu tinggi terhadap keberadaan komunitas Ahmadiyah di lingkungan mereka.

Sikap warga Ahmadiyah yang cenderung tidak menghormati keyakinan keislaman warga yang lain hingga terendus rencana bahwa Ahmadiyah hendak melakukan upaya merubah tatanan sosial dan kultural keislaman masyarakat Buton. Hal ini dinyatakan oleh ibu Salama, seorang warga Saragi, beliau juga menegaskan bahwa aspek sosiologis dan kultural lebih berperan dalam memicu kemarahan warga terhadap Ahmadiyah hingga berujung konflik dan perusakan aset warga Ahmadiyah di tahun 2006, 2007, 2009, dan 2010, ketimbang aspek perbedaan teologis maupun fikih. Seringnya datang jemaat dan tokoh-tokoh Ahmadiyah dari luar Saragi bahkan diantaranya sempat tinggal di Saragi, baik dari Kendari maupun dari Jawa juga dipersoalkan karena dianggap menggangu ketenangan warga Saragi. Pasca konflik 2006, warga Ahmadiyah yang bukan penduduk asli Saragi, kemudian diusir keluar serta ketika ada warga atau tokoh Ahamdiyah datang berkunjung ke Saragi akan diusir oleh warga.sehingga seorang warga Saragi menyatakan bahwa, selama mereka (jemaat Ahmadiyah Saragi) 
tidak membawa pendatang Ahmadiyah dari luar ke Saragi, maka jemaat Ahmadiyah yang ada di Saragi akan lebih aman, namun jika sebaliknya, maka konflik akan terulang kembali.

Interaksi Jemaat Ahmadiyah dengan warga sekitar dapat dikatakan tidak harmonis, meski diantara mereka masih memiliki hubungan kekerabatan. Hubungan perkenalan, pertemanan, bahkan kekeluargaan tidak cukup menjadi faktor yang membuat interaksi pergaulan berjalan dengan baik. Perbedaan anutan keislaman ini telah membuat renggangnya hubungan pertemanan dan bahkan hubungan kekeluargaan.

Terkait dengan hal ini, seorang informan dari warga Saragi mengatakan renggangnya hubungan antara masyarakat Saragi dengan Jemaat Ahmadiyah tampak dari adanya seruan dari tokoh agama dan masyarakat setempat untuk tidak mengundang warga Ahmadiyah dalam hajatan keluarga warga serta tidak mendatangi jika diundang oleh warga Ahamdiyah jika melakukan acara. Bahkan jika seorang warga mengadakan hajatan dan ada keluarganya yang anggota Ahmadiyah hadir, maka orang tersebut diusir dan jika tidak maka warga dan tokoh masyrakat yang lain tidak akan hadir. Pernah suatu hari seorang warga yang mengalami kedukaan, keluarganya yang menganut Ahmadiyah hadir untuk melayat, perangkat syara dan lebe (tokoh masyarakat yang dituakan) tidak akan mau untuk mengurus penyelenggaraan jenazah di rumah tersebut, jika orang Ahmadiyah yang hadir di tempat tersebut tidak pergi.pernah pula orang tua warga Ahmadiyah wafat, dan semua anak-anaknya adalah jemaat Ahmadiyah, meski almarhum bukanlah jemaat Ahmadiyah, perangkat syara dan lebe (tokoh adat) setempat baru mau mengurus jenazah tersebut jika anak-anaknya yang menjadi penganut Ahmadiyah keluar. Hal inilah yang membuat warga Saragi tidak akan pernah mau lagi mengundang atau menghadiri acara kerabat atau keluarga mereka yang menjadi pengikut kelompok Ahmadiyah. Sikap yang sama juga diterima oleh anak-anak warga Ahmadiyah di sekolah mereka, pernah seorang guru agama di SMAN I Pasarwajo menolak memberikan soal ujian agama kepada anak dari Lampio (pimpinan jemaat Ahmadiyah) dengan alasan bahwa anak tersebut bukan lagi seorang muslim,

Dari data di atas tampak adanya tindakan represi psikologis dan sosial terhadap warga Ahmadiyah dengan mengisolasi mereka untuk tidak berhubungan dengan sesama jemaat Ahmadiyah dari luar (dalam hal ini tidak boleh didatangi oleh sesama warga atau tokoh Ahmadiyah dari luar Saragi). Serta mengisolasi warga Ahmadiyah dari hubungan kekerabatan dan kekeluargaan serta sosial dengan masyarakat lainnya. Di samping penyerangan yang pernah dilakukan cara represi di atas ternyata cukup efektif untuk "menghabisi" laju gerak jemaat Ahmadiyah di Saragi. Terbukti ada beberapa warga Ahmadiyah yang kemudian keluar dari Saragi dan tak sedikit pula yang menyatakan diri keluar dari Ahmadiyah.

Hubungan sosial yang tidak harmonis antara warga pengikut Ahmadiyah dengan warga masyarakat lainnya yang telah menimbulkan konflik disebabkan pula oleh sikap eksklusifisme warga Ahmadiyah, dan klaim kebenaran yang kerap ditunjukkan oleh orang-orang Ahmadiyah terhadap keyakinan masyarakat muslim lainnya di Saragi. Kehadiran Ahmadiyah dianggap mengancam stabilitas tatanan sosial dan kultural keislaman masyarakat Buton, akibatnya masyarakat merasa perlu untuk mengambil langkah-langkah sosial untuk meredam ancaman tersebut. Kasus penyerangan terhadap warga Ahmadiyah di daerah lain, khususnya yang kemudian menjadi headline berita media nasiuonal menjadi faktor yang mempengaruhi pula keberanian masyarakat untuk melakukan tindakan anarkis.

Konflik kekerasan pertama antara warga masyarakat Saragi dengan pengikut Ahmadiyah terjadi pada tahun 2006, tak lama setelah terjadinya penyerangan terhadap markas Ahmadiyah di Parung, Bogor. Peristiwa Bogor ini diakui oleh Waode Anary cukup mempengaruhi keberanian massa untuk ikut juga melakukan penyerangan terhadap kelompok Ahmadiyah yang ada di Saragi. Pemerintah dan aparat terkait yang dinilai warga cukup lamban dalam menangani kelompok Ahmadiyah di Saragi juga mempengaruhi tindakan anarkisme yang dilakukan oleh warga setempat terhadap kelomppok Ahmadiyah.

\section{PENUTUP}

Jemaat Ahmadiyah pertama kali hadir di kabupaten Buton pada tahun 1983 dibawa oleh dua orang warga Buton yaitu Syamsuri La Una dan La Rangani, jemaat Ahmadiyah di Buton adalah aliran Qadian. Jemaat Ahmadiyah bermukim di kelurahan Saragi kecamatan Pasarwajo dan memiliki 53 orang pengikut. Metode dakwah yang digunakan adalah dengan pendekatan kekeluargaan dalam mengajak warga sekitar untuk menganut Ahmadiyah, selain 
itu pembagian buku-buku yang berisikan tentang ajaran Ahmadiyah dijadikan sebagai metode dakwah.

Masyarakat ternyata cukup resisten dengan keberadaan jemaat Ahmadiyah, hubungan antar keduanya tidak harmonis. Ketidakharmonisan hubungan ini berujung pada konflik horisontal antara warga dan jemaat Ahmadiyah yang terjadi setidaknya 4 kali, yaitu tahun 2006, 2007, 2009, dan 2010. Akibat respon masyarakat tersebut, aktivitas jemaat Ahmadiyah menjadi terbatasi, baik dalam dakwah maupun dalam kehidupan sehari-hari. Sikap eksklusifisme warga Ahmadiyah, ajaran yang dianggap menyimpang, serta pandangan bahwa kehadiran jemaat Ahmadiyah akan mengancam stabilitas kultur keislaman masyarakat Buton, membuat masyarakat bersikap reaktif terhadap jemaat Ahmadiyah.

\section{UCAPAN TERIMA KASIH}

Melalui tuliasn ini, peneliti mengucapkan terima kasih kepada berbagai pihak yang berkontribusi dalam penelitian ini. Peneliti mengucapkan terima kasih yang sebesar-besarnya kepada Balai Litbang Agama Makassar yang mendanai penelitian ini, juga kepada pihak kementerian agama kabupaten Buton, kantor kesbangpol kabupaten Buton, pemerintah kelurahan Saragi, pihak MTs kelurahan Saragi. Terkhusus peneliti mengucapkan terima aksih kepada bapak Drs. La Diri dan ibu Wa Ode Anary S. $\mathrm{Ag}$ atas bantuannya selama penelitian ini dilakukan.

\section{DAFTAR PUSTAKA}

Ahmad, Abdul Kadir (ed). 2007. Varian Gerakan Keagamaan. Makassar: CV. Indobis.

Ahmad, Haidlor Ali. 2007. Respon Pemerintah, Ormas, dan Masyarakat terhadap Aliran Keagamaan di Indonesia. Jakarta: Badan Litbang dan Diklat Departemen Agama RI.

Ahmad, Mirza Basyiruddin. 1997. Silsilah Ahmadiyah. Jakarta: Kemang.

Alifuddin. M. 2007. Islam Buton: Interaksi Islam dengan Budaya Lokal. Jakarta: Badan Litbang dan Diklat Depag RI.

BPS Kabupaten Buton, Buton dalam Angka 2012.

Data keagamaan Kementerian Agama Kabupaten Buton 2011.

Data Potensi Keluarahan Saragi Kecamatan Pasarwajo Kabupaten Buton 2012.

Gibb, Hamiltan AR. 2001. Aliran-aliran Modern dalam Islam. Jakarta: Rajagrafindo Persada.

Iqbal, Muhammad. 1991. Islam dan Ahamdiyah. Jakarta: Bumi Aksara.

Kurniawan, A. Fajar. 2006. Teologi Kenabian Ahmadiyah. Jakarta: RMBooks.

Nahdi, Shaleh A. 2001. Ahmadiyah Selayang Pandang. Jakarta: Yayasan Raja Pena.

Noer, Deliar. 1982. Gerakan Modern Islam di Indonesia 1900-1942. Jakarta: LP3ES.

Yasir, S. Ali. 1981. Pengantar Pembaharuan dalam Islam. Yogyakarta: Yayasan Perguruan Islam RI.

Zulkarnaen, Iskandar. 2005. Geraka Ahamdiyah di Indonesia. Yogyakarta: LkiS. 